\title{
ЕФЕКТИВНІСТЬ ГІСТЕРОРЕЗЕКТОСКОПІЇ У ЖІНОК З БЕЗПЛІДДЯМ НА ФОНІ ЛЕЙОМІОМИ МАТКИ В ПРОГРАМАХ ДОПОМІЖНИХ РЕПРОДУКТИВНИХ ТЕХНОЛОГІЙ
}

\author{
${ }^{1}$ ДВНЗ «Тернопільський державний медичний університет \\ імені І. Я. Горбачевського МОЗ України», м. Тернопіль, Україна \\ ${ }^{2}$ Медичний центр «Клініка профресора С. Хміля», м. Тернопіль, Україна \\ ${ }^{3}$ Тернопільський обласний клінічний перинатальний центр «Мати і дитина», м. Тернопіль, Україна
}

\begin{abstract}
Мета: вивчення ефективності гістерорезектоскопії у жінок із безпліддям на фоні лейоміоми матки в програмах допоміжних репродуктивних технологій.

Матеріали і методи. Рандомізоване клінічне дослідження проведено серед 58 жінок, які проходили лікування безпліддя шляхом використання програм допоміжних репродуктивних технологій. Вибірку було поділено на 2 групи. I групу (дослідну) склала 41 жінка з лейоміомою матки з субмукозним та субмукозно-інтрамуральним розташуванням міоматозних вузлів та невдалими спробами екстракорпорального запліднення в анамнезі, цим жінкам запропоновано гістерорезектоскопію як підготовку перед програмами допоміжних репродуктивних технологій. II групу (контрольну) - 17 жінок із лейоміомою матки з субмукозно-інтрамуральним розташуванням міоматозних вузлів, які відмовились від гістерорезектоскопії. У цьому дослідженні були включені пари виключно 3 жіночими формами безпліддя.

Результати. Доведено ефективність гістерорезектоскопії на результат циклів екстракорпорального запліднення у жінок з лейоміомою матки. У дослідній групі настання вагітності спостерігали у 17 жінок, що склало 41,5 \% (3 першої спроби екстракорпорального запліднення), ранні мимовільні викидні спостерігали в 2 жінок (11,8 \%), у 14 жінок вагітність закінчилась терміновими пологами (82,4 \%) та в однієї жінки передчасними (5,9 \%). У II групі (контрольній) з 17 пацієнток вагітність настала в 6 жінок (35,3 \%), 3 випадки ранніх мимовільних викиднів (50 \%), термінові пологи у 3 жінок (50\%).

Висновки. Лейоміома матки в основному $€$ причиною безпліддя за рахунок механічного фактора. Гістерорезектоскопія $€$ оптимальним методом прегравідарної підготовки у жінок із лейоміомою матки, які проходять лікування безпліддя шляхом використання допоміжних репродуктивних технологій. Гістерорезектоскопія $€$ органозберігаючою операцією, що має ряд переваг: легкий післяопераційний період, відсутність спайкового процесу, що, в свою чергу, підвищує частоту настання та виношування вагітності.
\end{abstract}

КЛЮЧОВІ СЛОВА: лейоміома матки; гістерорезектоскопія; агоністи гонадотропін-рилізинг-гормонів; безпліддя; допоміжні репродуктивні технології; екстракорпоральне запліднення; інтрацитоплазматичне введення сперматозоїда.

Найпоширенішою доброякісною гормонозалежною пухлиною жіночої статевої системи $є$ лейоміома матки (ЛМ) [1-3]. Доведено вплив лейоміоми матки на фрертильність жінок. Безпліддя $€$ частим явищем при цій патології $[3,4,8]$. Провідну роль у виникненні цього ускладнення в жінок 3 міомою матки відіграють механічні фрактори [1]. Фіброміома може бути причиною безпліддя, коли міоматозний вузол розташовується в ділянці трубних кутів, стискає інтерстиціальну частину маткової труби та порушує її прохідність [9]. Просвіт труби, її довжина та розташування можуть змінюватися при пухлинних процесах у матці залежно від локалізації та розмірів міоматозних вузлів. Наявність підслизової або інтрамуральної міоми слугує постійним подразником і нерідко призводить до порушення скоротливої активності міометрія, що спричиняє порушення імплантації ембріона [5]. При міомі матки нерідко збільшується та деформується її порожнина, відзначаються нерівності рельєфу ендометрія, що ускладнює прохідність сперматозоїдів та яйцеклітини. Крім того, порушення рецепторного апарату ендометрія, що виникає у хворих із цією патологією, може перешкоджати адекватній підготовці ендометрія до реалізації генеративної фрункції жінки [6]. За даними різних авторів, лейоміома матки є причиною жіночого безпліддя у 20-30 \% та в 15-30 \% призводить до невиношування вагітності [7]. Згідно з даними вітчизняних та зарубіжних дослідників, фріброміома матки має вагомий вплив на ефективність програм допоміжних репродуктивних технологій (ДРТ) [2, 10]. Міоматозні вузли значно знижують частоту позитивних результатів екстракорпорального запліднення (ЕКЗ) та підвищують частоту мимовільних викиднів, у результаті їх згубного впливу на імплантацію ембріонів, скоротливу фрункцію

(с) С. В. Хміль, Ю. Б. Дроздовська, М. С. Хміль, Н. Я. Чудійович, 2018 
міометрія [6]. На сьогодні достовірно не вирішено питання оптимального методу лікування жінок 3 лейоміомою матки та нереалізованим репродуктивним потенціалом. Таким чином, вивчення сучасних методів хірургічного лікування хворих із цим пухлинним процесом $є$ актуальним завданням акушерства, гінекології та репродуктології.

Мета роботи: вивчення еорективності гістерорезектоскопії у жінок із безпліддям на фоні лейоміоми матки в програмах допоміжних репродуктивних технологій.

Матеріали і методи. Рандомізоване клінічне дослідження було проведено на базі Медичного центру «Клініка профресора С. Хміля» за період із 2010 до 2018 р., нами досліджено 58 жінок, які проходили лікування безпліддя шляхом використання допоміжних репродуктивних технологій 3 верифрікованим діагнозом ЛМ та такими характеристиками: вік $(33,9 \pm 7,8)$ року (26-42 років), IMT $(23,5 \pm 5,2) \mathrm{\kappa г} / \mathrm{M}^{2}$, АМГ - 1,8 ng/ml $(0,4-5,2 \mathrm{ng} / \mathrm{ml})$. Тривалість безпліддя - 2-15 років у середньому $(5,4 \pm 0,5)$ року. Первинне безпліддя було в 14 пацієнток (24,1\%), а вторинне - у 44 жінок (75,9\%). Середній вік жінок, у якому починалось менархе, склав $(13,0 \pm 0,5)$ року, в усіх жінок менструальний цикл був регулярним.

У дослідження були включені подружні пари виключно 3 жіночим фрактором безпліддя. Спермограма чоловіків перебувала у межах фрізіологічної норми. Вибірку було поділено на 2 групи. I групу (дослідну) склала 41 пацієнтка з лейоміомою матки 3 субмукозним та субмукозно-інтрамуральним розташуванням міоматозних вузлів. Розміри ффіброматозних вузлів не перевищували 3-4 см у діаметрі, в усіх жінок була деформована порожнина матки та невдалі спроби екстракорпорального запліднення в минулому. Усім пацієнткам I групи було запропоновано гістерорезектоскопію в якості лікування та підготовки перед програмами допоміжних репродуктивних технологій. Жінкам із субмукозно-інтрамуральним розташуванням міоматозних вузлів проводили гормональну підготовку агоністами гонадотропін-рилізинг-гормонів («Диоререлін» 3,75 мг внутрішньом'язово 1 раз на 28 днів протягом 3 місяців) перед міомектомією. Мета передопераційного лікування гормонами полягає у зменшенні розмірів вузла (на 30-40 \%), при якому вузол «видавлюється» в порожнину матки, що полегшує проведення органозберігаючого операційного втручання. II групу (контрольну) - 17 жінок із лейоміомою матки з субмукозноінтрамуральним розташуванням міоматозного вузла, які відмовились від гістерорезектоскопії.

Обстеження та лікування подружніх пар проводили відповідно до наказу Міністерства охорони здоров'я України від 09.09.2013 р. № 787 «ро затвердження порядку застосування допоміжних репродуктивних технологій в Україні».
Результати дослідження та їх обговорення. Жінкам у дослідній групі було проведено гістерорезектоскопію - сучасний органозберігаючий малоінвазивний хірургічний метод лікування пацієнтів із лейоміомою матки.

Пацієнткам із субмукозною міомою лікування проводили в один етап, а з субмукозно-інтрамуральним розташуванням міоматозного вузла в два етапи. Після попередньої гормональної підготовки здійснювали гістерорезектоскопію 3 міомектомією, після якої пацієнткам ще на 2 місяці призначали лікування агоністами гонадотропін-рилізинг-гормонів («Диферелін» 3,75 мг внутрішньом'язово 1 раз на 28 днів), та виконували повторну операцію. Після повторного лікування дифереліном залишки міоматозного вузла «видавлювали» в порожнину матки, що давало можливість хірургу повністю видалити фріброматозний вузол.

Гістерорезектоскопію проводили механічним та електрохірургічним шляхом на 6-10 дні менструального циклу під загальним знеболюванням. Пацієнток укладали у дорсальне літотомічне положення. Операційне втручання виконували гістерорезектоскопом компанії Karl Storz. Після попередньої обробки операційного поля антисептичними розчинами, в асептичних умовах шийка матки оголювалась в дзеркалах; за допомогою кульових щипців захоплювали та фріксували за передню губу. Матковим зондом вимірювали напрям осі та довжину матки. Розширення цервікального каналу проводили за допомогою розширювачів Гегара до № 8. Після цього в порожнину матки вводили гістероскоп. Під контролем телевізійної камери, поступово здійснювали огляд та оцінювали стан порожнини матки, кутів матки, огляд вічка маткових труб, стан ендометрія, наявність та локалізацію патологічних утворень, цервікальний канал. Лише після повної оцінки порожнини матки розпочинають операційне втручання. Гістерорезектоскоп являє собою спеціалізований електрохірургічний ендоскоп, який складається з тубуса, з'єднувальних трубок для постійної промивки дистензійними середовищами (Турусол) та їх аспірації, зовнішньої та внутрішньої трубок, стандартного обтуратора та робочих елементів (ріжуча чи коагулююча петля). Вибір методу втручання залежав від локалізації та розмірів міоматозного вузла.

Механічним шляхом за допомогою ріжучої петлі проводили видалення субмукозних міоматозних вузлів на тонкій ніжці, в ділянці дна матки. Електрохірургічним шляхом (петлевим електродом) було проведено резекцію міоматозних вузлів із субмукозно-інтрамуральним розташуванням та субмукозних вузлів на широкій ніжці. Під час цієї методики тканина вузла поступово зрізається тоненькими смужками. Рух гістероскопа 
має бути строго у напрямку до хірурга (попередження перфорації матки). Під час операції періодично видаляють тканини міоматозного вузла. Усім пацієнткам після проведеного операційного втручання було призначено адекватну гемостатичну, антибактеріальну та гормональну терапії.

Усі 58 подружніх пар проходили лікування безпліддя шляхом інтрацитоплазматичного введення сперматозоїда (IKCl).

Жінкам обох груп перед початком проведення контрольованої стимуляції овуляції протягом 2-3 місяців проводили прегравідарну підготовку вітамінним комплексом «FT-500 Plus», що містить у своєму складі: інозитол - 2000 мг, вітамін С 160 мг, вітамін Е - 12 мг, фролієву кислоту 400 мкг, селен - 55 мкг, глутатіон - 50 мг, цинк 10 мг, лютеїн - 3 мг. Контрольовану стимуляцію суперовуляції здійснювали за допомогою коротких протоколів із використанням рекомбінантного гонадотропіну корифролітропіну-альфа «ЕЛОНВА». Цей препарат має пролонговану дію (7-8 днів). На 5-7 дні стимуляції, під контролем фолікулометрії, при досягненні фолікулами розмірів у діаметрі 14-15 мм, призначали щоденно антагоніст гонадотропін-рилізинг-гормонів «Оргалутран» по 0,25 мг. На 8 день стимуляцію суперовуляції продовжували рекомбінантним ФСГ «Пурегон» до фрінального дозрівання ооцитів (наявність щонайменше 3 ооцитів діаметром більше 17 мм), як тригер використовували агоніст гонадотропін-рилізинг-гормон «Диферелін» чи людський хоріонічний гонадотропін «Хоріомон» чи «Прегніл» в дозі 5000 чи 10000 ОД. Через 36-37 год після введення тригера овуляції проводили пункцію фролікулів із подальшою аспірацією ооцитів. Після попередньої оцінки стану яйцеклітин ембріологами, проводили їх запліднення методом ІKCІ. Лише ооцити на стадії профази I другого мейотичного поділу придатні до запліднення. Запліднення яйцеклітин та культивування ембріонів із подальшим перенесенням їх у порожнину матки чи вітрифікацією на 5-6 доби (стадія бластоцисти) здійснювали в умовах ембріологічної лабораторії. Ембріотрансфер у порожнину матки проводили як у свіжих, так і у кріоциклах, залежно від ризику виникнення синдрому гіперстимуляції яєчників у пацієнток. Пацієнтки отримували підтримувальну терапію естрогенними («Прогінова») та гестагенними препаратами до отримання результату про наявність вагітності. Визначення вагітності проводили через 2 тижні після ембріотрансфреру шляхом аналізу крові на $\beta$-ХГЛ. При позитивному результаті підтримувальну терапію продовжували до 8-12 тижнів вагітності.

У дослідній групі настання вагітності спостерігали у 17 жінок, що склало 41,5 \% (3 першої спроби ЕКЗ), ранні мимовільні викидні - у 2 жінок
(11,8 \%), в 14 жінок вагітність завершилась терміновими пологами (82,4 \%) та в однієї жінки передчасними (5,9%). У II групі (контрольній) 3 17 пацієнток вагітність настала в 6 жінок (35,3\%), 3 випадки ранніх мимовільних викиднів (50\%), термінові пологи у 3 жінок (50 \%).

Доведено вагомий вплив гістерорезектоскопії на еорективність програм допоміжних репродуктивних технологій. У дослідженні висвітлено високу частоту настання та виношування вагітності у жінок I групи (дослідної), яким проводили гістерорезектоскопію, порівняно 3 контрольною групою. Таким чином, можна стверджувати, що гістерорезектоскопія $є$ оптимальним методом вибору лікування молодих жінок із субмукозною та субмукозно-інтрамуральною лейоміомою матки. Перевагами гістерорезектоскопії $€$ збереження органа, значне зменшення операційної травми, менш виражений в подальшому спайковий процес, що підвищує ймовірність настання вагітності, коротка тривалість операційного втручання, легкий післяопераційний період.

На сьогодні хірургічне лікування лейоміоми матки у жінок молодого віку 3 нереалізованим репродуктивним потенціалом включає органозберігаючі операції - консервативну міомектомію, яку залежно від локалізації вузлів та показань виконують різними доступами: гістероскопічним, лапароскопічним та лапаротомним. Проте втручання в порожнину малого таза може погіршити репродуктивну функцію жінки через фрормування спайкового процесу, рубців на матці, що, в свою чергу, і призводить до безпліддя.

\section{Висновки}

1. Лейоміома матки в основному є причиною безпліддя за рахунок механічного фрактора: дефрормація порожнини матки, порушення транспорту та міграції сперматозоїдів та яйцеклітини, порушення імплантації ембріона, скоротливої фрункції міометрія.

2. Перевагами гістерорезектоскопії $€$ збереження органа, значне зменшення операційної травми, менш виражений в подальшому спайковий процес, що підвищує ймовірність настання вагітності, легкий післяопераційний період.

3. Гістерорезектоскопія $€$ оптимальним методом підготовки та лікування жінок із лейоміомою матки у програмах допоміжних репродуктивних технологій, що, в свою чергу, значно підвищує частоту настання та виношування вагітності.

Перспективи подальших досліджень передбачають підхід до вибору оптимальних методів лікування жінок із лейоміомою матки та нереалізованим репродуктивним потенціалом, що проходять лікування безпліддя у циклах екстракорпорального запліднення. 


\section{Список літератури}

1. Дорогая О. П. Оптимізація методу відновлення репродуктивної фрункції у жінок із субмукозною міомою матки / О. П. Дорогая // Клінічна ендокринологія та ендокринна хірургія. - 2014. - № 3 (48). - С. 47-52.

2. Жилка Н. Я. Інноваційні підходи до лікування лейоміоми матки / Н. Я. Жилка // Здоровье женщины. - 2016. № 7 (113). - С. 104-106.

3. Сучасні погляди репродуктолога на етіопатогенез і лікування лейоміоми матки / Н. В. Авраменко, Д. Є. Барковський, О. В. Кабаченко, Д. В. Лецин // Запорізький медичний журнал. - 2017. - Т. 19, № 3 (102). C. $381-386$.

4. Сучасні погляди на етіологію, патогенез та лікування лейоміоми матки у жінок репродуктивного віку (огляд літератури) / А. Г. Корнацька, І. І. Ракша, І. С. Колесніченко, Г. В. Чубей // Здоровье женщины. - 2015. - № 1 (97). - С. $10-13$. 5. Чайка К. В. Комплексное эндохирургическое лечение женщин репродуктивного возраста с субмукозной миомой матки / К. В. Чайка, О. Л. Писарева // Медико-соціальні проблеми сім'ї. - 2013. - Т. 18, № 3. - С. $63-67$.

6. Alterations in uterine hemodynamics caused by uterine fibroids and their impact on in vitro fertilization outcomes / JeiWon Moon, Chung-Hoon Kim, Jun-Bum Kim [et al.] // Clin. Exp. Reprod. Med. - 2015. - Vol. 42 (4). - P. 163-168.

7. Deligdish L. Endometrial changes associated with myomata of uterus // L. Deligdish, M. Loewenthal // J. CHn Pathol. 2014. - No. 23. - P. 676-680.

8. Infertility and uterine fibroids. / LI Zepiridis, GF Grimbizis, BC Tarlatzis [et al.] // Best Pract. Res. Clin. Obstet. Gynaecol. 2016. - Vol. 34. - P. 66-73.

9. Potential of minimally invasive procedures in the treatment of uterine fibroids: a focus on magnetic resonanceguidet focused ultrasound therapy / K. Fischer, N. J. McDannold, C. M. Tempany // Int. J. Womens Health. - 2015. Vol. 7. - P. 901-912.

10. Samejima T. Identifying patients who can improve fertility with myomectomy / T. Samejima, K. Koga, H. Naake [et al.] // Eur. J. Obstet. Gynecol. Reprod. Biol. - 2015. - Vol. 185. - P. 28-32.

\section{References}

1. Dorohaia, O.P. (2014). Optymizatsiia metodu vidnovlennia reproduktyvnoi funktsii u zhinok iz submukoznoiu miomoiu matky [Optimization of the method of restoration of the reproductive function in women with submucous uterine myoma]. Klinichna endokrynolohiia ta endokrynna khirurhiia - Clinical Endocrinology and Endocrine Surgery, 3 (48), 47-52 [in Ukrainian].

2. Zhylka, N.Ya. (2016). Innovatsiini pidkhody do likuvannia leiomiomy matky [Innovative approaches to treatment of uterine leiomyomas]. Zdorovie zhenshchiny - Health of a Woman, 7 (113), 104-106 [in Ukrainian].

3. Avramenko, N.V., Barkovskyi, D.Ye., Kabachenko, O.V., \& Letsyn, D.V. Suchasni pohliady reproduktoloha na etiopatohenez i likuvannia leiomiomy matky [Modern views of the reproductionist on etiopathogenesis and treatment of uterine leiomyomas]. Zaporizkyi medychnyi zhurnal - Zaporizhzhia Medical Journal, 3 (102), $381-386$ [in Ukrainian].

4. Kornatska, A.H., Raksha, I.I., Kolesnychenko, I.S., \& Chubei, H.V. (2015). Suchasni pohliady na etiolohiiu, patohenez ta likuvannia leiomiomy matky u zhinok reproduktyvnoho viku (ohliad literatury) [Modern views on the etiology, pathogenesis and treatment of uterine leiomyomas in women of reproductive age (review of literature)]. Zdorovie zhenshchiny - Health of a Woman, 1 (97), 10-13 [in Ukrainian].

5. Chayka, K.V., \& Pisareva, O.L. (2013). Kompleksnoye endokhirurgicheskoye lecheniye zhenshchin reproduktivnogo vozrasta s submukoznoy miomoy matki [Complex endosurgical treatment of women of reproductive age with submucosal uterine fibroids]. Medyko-sotsialni problemy simi - Medical and Social Problems of a Family, 18 (3), $63-67$ [in Russian]. 6. Jei-Won Moon, Chung-Hoon Kim, \& Jun-Bum Kim (2015). Alterations in uterine hemodynamics caused by uterine fibroids and their impact on in vitro fertilization outcomes. Clin. Exp. Reprod. Med, 42 (4). 163-168.

7. Deligdish, L. \& Loewenthal, M. (2014). Endometrial changes associated with myomata of uterus. J. CHn Pathol., 23, 676-680. 8. Samejima, T., Koga, K., Naake, H., Wada-Hiraike, O., Fujimoto, A., Fujii, T., Osuga, Y. Identifying patients who can improve fertility with myomectomy. (2015). Eur. J. Obstet. Gynecol. Reprod. Biol., 185, 28-32.

9. Zepiridis, L.I., Grimbizis, G.F., \& Tarlatzis, B.C. (2016). Infertility and uterine fibroids. Best Pract. Res. Clin. Obstet. Gynaecol., 34, 66-73.

10. Fischer, K., McDannold, N.J., \& Tempany, C.M. (2015). Potential of minimally invasive procedures in the treatment of uterine fibroids: a focus on magnetic resonance-guidet focused ultrasound therapy. Int. J. Women Health, (7), 901-902.

11. Samejima, T., Koga, K., Naake, H., \& Wada-Hiraike, O. (2015). Identifying patients who can improve fertility with myomectomy. Eur. J. Obstet. Gynecol. Reprod. Biol., (185), 28-32.

\section{ЭФФЕКТИВНОСТЬ ГИСТЕРОРЕЗЕКТОСКОПИИ У ЖЕНЩИН С БЕСПЛОДИЕМ НА ФОНЕ ЛЕЙОМИОМЫ МАТКИ В ПРОГРАММАХ ВСПОМОГАТЕЛЬНЫХ РЕПРОДУКТИВНЫХ ТЕХНОЛОГИЙ}

С. В. Хмиль ${ }^{1,2}$ Ю. Б. Дроздовская ${ }^{1}$, М. С. Хмиль ${ }^{1,2}$, Н. Я. Чудийович ${ }^{3}$

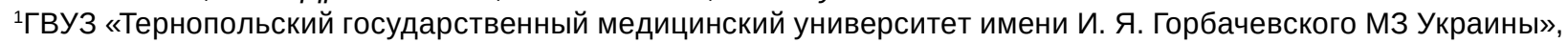

г. Тернополь, Украина

${ }^{2}$ Медицинский центр «Клиника профрессора С. Хмиля», г. Тернополь, Украина

${ }^{3}$ Тернопольский областной клинический перинатальный центр «Мать и ребенок», г. Тернополь, Украина

Цель: изучение эффрективности гистерорезектоскопии у женщин с бесплодием на фроне лейомиомы матки в программах вспомогательных репродуктивных технологий.

Материалы и методы. Рандомизированное клиническое исследование проведено среди 58 женщин, проходивших лечение бесплодия путем использования программ вспомогательных репродуктивных технологий. Выборка была разделена на 2 группы. I группу (исследовательскую) составляла 41 женщина с 
лейомиомой матки с субмукозным и субмукозно-интрамуральным размещением миоматозных узлов и неудачными попытками экстракорпорального оплодотворения в анамнезе, этим женщинам предложено гистерорезектоскопию как подготовку перед программами вспомогательных репродуктивных технологий. II группу (контрольную) - 17 женщин с лейомиомой матки с субмукозно-интрамуралным размещением миоматозных узлов, которые отказались от гистерорезектоскопии. В данном исследовании были включены пары исключительно с женскими фрормами бесплодия.

Результаты. Доказана эфффективность гистерорезектоскопии на результат циклов экстракорпорального оплодотворения у женщин с лейомиомой матки. В исследовательской группе наступление беременности наблюдали в 17 женщин, что составляло 41,5% (с первой попытки экстракорпорального оплодотворения), ранние самопроизвольные выкидыши наблюдали в 2 женщин (11,8 \%), у 14 женщин беременность закончилась срочными родами (82,4 \%) и в одной женщины преждевременными (5,9 \%). В II группе (контрольной) беременность наступила у 6 женщин (35,3\%), 3 случая ранних самопроизвольных выкидышей (50 \%), срочные роды у 3 женщин (50 \%).

Выводы. Лейомиома матки в основном является причиной бесплодия за счет механического фактора. Гистерорезектоскопия является оптимальным методом прегравидарной подготовки у женщин с лейомиомой матки, проходящих лечение бесплодия путем использования вспомогательных репродуктивных технологий. Гистерорезектоскопия это органосохраняющая операция, которая имеет ряд преимуществ: легкий послеоперационный период, отсутствие спаечного процесса, что, в свою очередь, повышает частоту наступления и вынашивания беременности.

КЛЮЧЕВЫЕ СЛОВА: лейомиома матки; гистерорезектоскопия; агонисты гонадотропин-рилизинггормонов; бесплодие; вспомогательные репродуктивные технологии; экстракорпоральное оплодотворение; интрацитоплазматическое введение сперматозоида.

\section{EFFECTIVENESS OF HYSTEROREZECTOSCOPY IN WOMEN WITH INFERTILITY AND UTERINE FIBROIDS IN PROGRAMS OF ASSISTED REPRODUCTIVE TECHNOLOGIES}

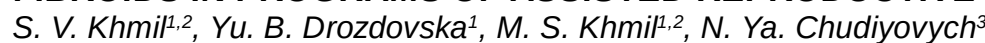

${ }^{1}$ I. Horbachevsky Ternopil State Medical University, Ternopil, Ukraine

${ }^{2}$ Medical Center "Professor S. Khmil Clinic", Ternopil, Ukraine

${ }^{3}$ TernopilRegional Clinical Perinatal Center "Mother and Child", Ternopil, Ukraine

Purpose: studying of the effectiveness of hysterorezectoscopy in women with infertility and uterine fibroids in the cycles of in vitro fertilization.

Materials and Methods. A randomized clinical trial was conduct among 58 women undergoing infertility treatment using assisted reproductive technologies (ART). The selection was divided into 2 groups. The group 1 (study) consisted of 41 women with uterus fibroids with submucosal and submucosally-intramural placement of myomatous nodes and failed attempts of IVF in history, these women were offered hysterorezectoscopy, as preparation for programs of assisted reproductive technologies. The froup 2 (control) - 17 women with uterine fibroids with submucosally-intramural placement of myomatous nodes, who refused hysterorezectoscopy. In this study, couples were included exclusively with female infertility.

Results. The effectiveness of hysterorezectoscopy on the outcome of IVF cycles in women with uterine fibroids was proved. In the study group, 17 women had an onset of pregnancy, which was $41.5 \%$ (after I attempted IVF), early spontaneous miscarriages were observed in 2 women (11.8\%), in 14 women pregnancy ended in timely partum (82.4\%) and 1 woman had premature partum $(5.9 \%)$. In the control group pregnancy occurred in 6 women (35.3\%), 3 cases of early spontaneous miscarriages (50\%), timely births in 3 women (50\%).

Conclusions. The uterine fibroids is basically a cause of infertility due to a mechanical factor. Hysterorezectoscopy is the best method of pregravid preparation in women with uterine fibroids, undergoing infertility treatment during the use of assisted reproductive technologies. Hysterorezectoscopy is an organ saving operation that has several advantages: a mild postoperative period, a lack of adhesive process, which in turn increases the incidence and onset of pregnancy.

KEY WORDS: uterus fibroid; hysterorezectoscopy; agonists of gonadotrophin-releasing hormones; infertility; assisted reproductive technologies; in vitro fertilization; intracytoplasmatic sperm injection.

Рукопис надійшов до редакції 21.11.2018 p.

\section{Відомості про авторів:}

Хміль Стефан Володимирович - професор кафедри акушерства та гінекології № 1 ДВНЗ «Тернопільський державний медичний університет імені І. Я. Горбачевського МОЗ України» заслужений діяч науки і техніки України, професор, доктор медичних наук. Директор Медичного центру «Клініка професора С. Хміля».

Дроздовська Юлія Богданівна - аспірант кафедри акушерства та гінекології № 1 ДВН3 «Тернопільський державний медичний університет імені І. Я. Горбачевського МОЗ України»; тел.: +38(068) 583-67-39.

Хміль Марія Стефанівна - асистент кафедри акушерства та гінекології № 1 ДВНЗ «Тернопільський державний медичний університет імені І. Я. Горбачевського МОЗ України». Медичний директор Медичного центру «Клініка профресора С. Хміля»; тел.: +38(067) 846-35-34.

Чудійович Наталя Ярославівна - лікар-інтерн акушер-гінеколог ТОКПЦ «Мати і дитина»; тел.: +38(098) 711-12-78. 